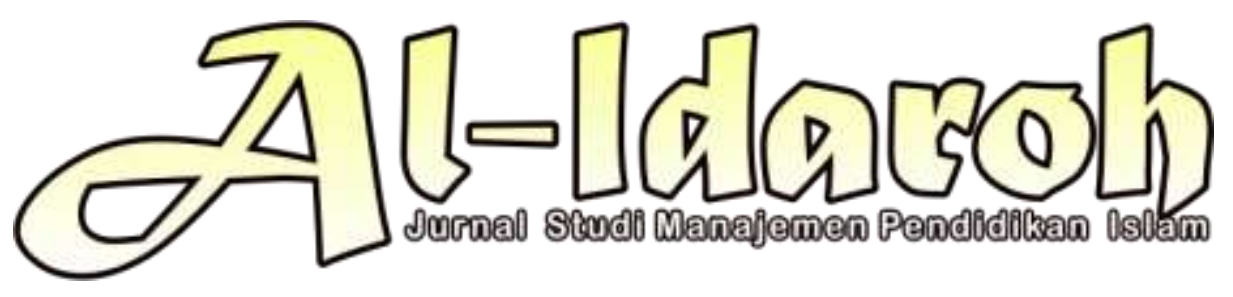

\title{
STRATEGI PROMOSI JASA PENDIDIKAN DI PONDOK PESANTREN NURUL ULUM KABUPATEN BLITAR
}

\author{
Nurdelima Waruwu \\ Universitas Islam Negeri Syarif Hidayatullah Jakarta \\ Email: nurdelima@,uinjkt.ac.id \\ Zahrotul Munawwaroh \\ Universitas Islam Negeri Syarif Hidayatullah Jakarta \\ Email: zahrotul.munawwaroh@,uinjkt.ac.id \\ Syifa' Nurda Mu'affa \\ Universitas Islam Negeri Syarif Hidayatullah Jakarta \\ Email: syifanurdamuaffa@gmail.com
}

\begin{abstract}
Promotion is a marketing activity carried out by the company (school) to introduce to the public (community) about the products they have. This study aims to determine the promotion strategy through the marketing mix of educational services at the Nurul Ulum Islamic Boarding School, Blitar Regency, which is a broad unified plan for the long term and is integrated with all available resources and connects strengths, weaknesses, opportunities, and threats. This study uses a qualitative approach with a descriptive method. The data sources were selected purposively and snowball sampling. The research data was collected through interviews, observations, and document studies. Data analysis was carried out with qualitative analysis techniques which included data collection, data reduction, data presentation, and drawing conclusions. Meanwhile, to check the validity of the data, the researcher used triangulation techniques, namely data triangulation and method triangulation. The results of the research conducted by the authors show that the promotion carried out by the Nurul Ulum Islamic Boarding School in Blitar Regency has been carried out well. The implementation of the promotion strategy through the $7 P$ mix (product, price, place, promotion, people, physical evidence, process) went quite well even though there was no planning and special program for each promotional mix activity carried out.
\end{abstract}

Keywords: Education Services, Promotion, Strategy

Al-Idaroh: Jurnal Studi Manajemen Pendidikan Islam

Volume 5 Nomor 2 September 2021; p-ISSN: 2549-8339; e-ISSN: 2579-3683 


\section{Pendahuluan}

Pondok pesantren kini sudah menjadi sebuah lembaga pendidikan yang mengakar dan menyebar di lingkungan masyarakat. Penyelenggaraan pendidikan pesantren juga sudah diakui menjadi bagian dari penyelenggaran sistem pendidikan nasional. Undang-Undang Nomor 18 Tahun 2019 tentang Pesantren memberikan landasan hukum bagi keberadaan dan peran pesantren di negara Indonesia.

Menurut undang-undang tersebut, setidaknya ada tiga fungsi yang dimiliki pesantren, yaitu pendidikan, dakwah, dan pemberdayaan masyarakat. Selain itu, undang-undang juga menyebutkan bahwa tujuan penyelenggaraan pesantren adalah 1) membentuk individu yang unggul di berbagai bidang yang memahami dan mengamalkan nilai ajaran agamanya dan atau menjadi ahli ilmu agama yang beriman, bertakwa, berakhlak mulia, berilmu, mandiri, tolong-menolong, seimbang, dan moderat, 2) membentuk pemahaman agama dan keberagamaan yang moderat dan cinta tanah air serta membentuk perilaku yang mendorong terciptanya kerukunan hidup beragama, 3) meningkatkan kualitas hidup masyarakat yang berdaya dalam memenuhi kebutuhan pendidikan warga negara dan kesejahteraan sosial masyarakat.

Sebagai lembaga pendidikan yang profesional, pondok pesantren harus memiliki tujuan. Demi mencapai tujuan, pesantren harus mempunyai santri yang akan mengikuti proses pembelajaran dan untuk pengembangan lembaga pendidikan. Hal pertama yang harus dilakukan pesantren agar memiliki santri adalah mengenalkan pesantren kepada masyarakat agar mereka tahu dan tertarik kepada pesantren melalui proses promosi.

Studi pendahuluan menunjukkan bahwa Pondok Pesantren Nurul Ulum Kabupaten Blitar masih belum maksimal dalam melakukan promosi pesantren. Kendati demikian, selama ini pesantren tersebut cukup banyak menarik calon santri baru, itu terlihat dari jumlah calon santri yang selalu memenuhi kuota bahkan lebih. Selain itu waktu pendaftaran calon santri baru harus ditutup lebih awal karena pihak pondok pesantren tidak mau kelebihan kuota.

Penelitian ini bertujuan untuk mengetahui strategi promosi yang dilakukan di Pondok Pesantren Nurul Ulum Kabupaten Blitar serta mengetahui kelebihan dan kelemahan promosi di Pondok Pesantren Nurul Ulum Kabupaten Blitar. Pendekatan yang digunakan dalam penelitian ini adalah kualitatif, sedangkan metode yang 


\section{Strategi Promosi Jasa Pendidikan di Pondok Pesantren Nurul Ulum \\ Kabupaten Blitar}

digunakan dalam penelitian ini adalah deskriptif. Teknik pengumpulan data yang digunakan dalam penelitian ini adalah wawancara, observasi, dan dokumentasi. Analisis data dilakukan dengan teknik analisis kualitatif sebagaimana yang dikemukakan oleh Miles dan Hubberman yaitu pengumpulan data, reduksi data, penyajian data dan penarikan kesimpulan. Dalam penelitian ini, untuk mengecek keabsahan data yang diperoleh peneliti menggunakan dua macam triangulasi yaitu: triangulasi sumber dan triangulasi metode.

\section{Pembahasan}

\section{Jasa Pendidikan}

Kata jasa (service) secara sederhana menurut Zeithaml, Bitner, dan Gremler dalam Dickens dan Simon diartikan sebagai deeds, processes, or performance provided by one party (person or group) to benefit another. ${ }^{1}$ Sementara itu, pendidikan adalah usaha sadar dan terencana untuk mewujudkan suasana belajar dan proses pembelajaran agar peserta didik secara aktif mengembangkan potensi dirinya. Berdasarkan definisi tersebut, jasa pendidikan dapat diartikan sebagai seluruh kegiatan baik yang berupa aktivitas ataupun kinerja yang berhubungan dengan pendidikan yang mengutamakan pelayanan dalam prosesnya.

Karakteristik jasa diantaraya adalah intangibility, inseparability (or simultaneous production and consumption), variability (or heterogeneity), and perishability. ${ }^{2}$ Lebih spesifik terkait dengan jasa pendidikan, buku The Economics of Education menyebutkan tiga ciri utama yang menjadi karakteristik jasa pendidikan, yaitu: (1) Lebih bersifat tidak berwujud dari pada berwujud, (2) Produksi dan konsumsi bersamaan waktu, (3) Kurang memiliki standar dan keseragaman. ${ }^{3}$

Produk jasa pendidikan secara umum dapat dirinci atas dua layanan yaitu; (1) layanan pokok yang terdiri dari personil pelayanan pengajaran, personil pelayanan admisitrasi, personil pelayanan fasilitas sekolah dan personil pelayanan

${ }^{1}$ Dickens Ouma Mawere dan Kipkorir Sitienei Chris Simon, "Technology and Performance Management: Strategies in Quality Service Delivery", Global Journal of Management and Business Research, Volume XXI, Issue VI, Edisi 2021, 49.

2Peter Mudie dan Angela Pirrie, Services Marketing Management, (London: Routledge, 2011), 3-5.

${ }^{3}$ Veithzal Rivai Zainal, Haryadi Kamal, dan Natsir Muhammad, The Economics of Education; Mengelola Pendidikan secara Profesional untuk. Meraih Mutu dengan Pendekatan Bisnis, (Jakarta: Gramedia Pustaka Utama, 2014), 362-363. 
murid atau siswa, serta (2) layanan bantu yang berbentuk pelayanan perpustakaan, pelayanan Gedung dan halaman sekolah. ${ }^{4}$ Produk jasa pendidikan hanya bisa dikonsumsi oleh konsumen pada saat proses produksi berlangsung.

\section{Strategi Promosi}

Sucherly dan Jain dalam Zulki Zulkifli mengatakan bahwa strategi merupakan suatu kesatuan rencana yang luas dan terintegrasi yang menghubungkan antara kekuatan internal perusahaan dengan peluang dan ancaman lingkungan eksternal. ${ }^{5}$ Sedangkan definisi promosi adalah komunikasi dari para pemasar yang menginformasikan, membujuk, dan mengingatkan para calon pembeli suatu produk dalam rangka mempengaruhi pendapat mereka atau memperoleh suatu respons. ${ }^{6}$ Berdasarkan definisi tersebut, strategi promosi dipahami sebagai kesatuan rencana yang menggunakan secara optimal kombinasi dari unsur-unsur bauran pemasaran dengan tujuan menginformasikan, membujuk, dan mengingatkan konsumen jasa.

Ada banyak jenis bauran pemasaran yang dikemukakan oleh para ahli. Bauran pemasaran yang digunakan dalam penelitian ini mengacu pada pendapat Booms dan Bitner karena penelitian ini berkaitan dengan pemasaran jasa. Tujuh bauran pemasaran jasa atau yang lebih dikenal dengan istilah 7P meliputi product, price, place, promotion, people, physical evidence, process.

Product sebagai sesuatu yang dapat ditawarkan ke pasar untuk mendapatkan perhatian, untuk dibeli, digunakan, atau dikonsumsi yang dapat memenuhi suatu keinginan atau kebutuhan. ${ }^{7}$ Produk dengan kata lain adalah keseluruhan objek atau proses yang memberikan sejumlah nilai kepada konsumen. Dalam strategi promosi, strategi produk merupakan unsur inti pada pemasaran. Pemilihan jenis produk yang akan dihasilkan akan menentukan kegiatan promosi yang dibutuhkan.

${ }^{4}$ Oteng Sutisna, Administrasi Pendidikan, Dasar Teoritis untuk Praktik Prefesional, (Bandung, Aksara, 1985), 65.

${ }^{5}$ Zulki Zulkifli Noor, Manajemen Pemasaran Stratejik dilengkapi dengan Kasus-Kasus dalam Bidang Bisnis dan Sektor Publik Tabun 2016, (Yogyakarta: Deepublish, 2020), 26.

${ }^{6}$ Charles W. Lamb, Joseph F. Hair, dan Carl McDaniel, Pemasaran, (Jakarta: Salemba Empat, 2001), 145.

7Philip Kotler dan Gary Amstrong, Dasar-Dasar Pemasaran, (Jakarta: Intermedia, 1995), 444-445. 


\section{Strategi Promosi Jasa Pendidikan di Pondok Pesantren Nurul Ulum \\ Kabupaten Blitar}

Price dalam pemasaran adalah jumlah uang yang harus dibayarkan oleh konsumen untuk mendapatkan suatu produk. ${ }^{8}$ Bagi konsumen, harga merupakan salah satu faktor terpenting dalam keputusan pembelian. Dalam konteks jasa pendidikan, harga adalah seluruh biaya yang dikeluarkan untuk mendapatkan jasa pendidikan yang ditawarkan. Elemen harga pendidikan meliputi biaya bulanan SPP (Sumbangan Pembinaan Pendidikan), investasi bangunan, dan lain-lain.

Place berarti berhubungan dengan di mana perusahaan jasa harus bermarkas dan melakukan aktivitas kegiatannya. ${ }^{9}$ Lokasi dalam kaitannya dengan pemasaran jasa pendidikan berarti tempat lembaga pendidikan berada. Hal tersebut sedikit banyak menjadi prefensi calon pelanggan dalam menentukan pilihannya. Lokasi yang strategis, nyaman dan mudah dijangkau akan menjadi daya tarik tersendiri.

Promotion adalah kegiatan mengkomunikasikan penjualan produk di pasaran yang berhubungan langsung dengan masyarakat. ${ }^{10}$ Promosi bertujuan untuk memberikan informasi dan meyakinkan konsumen akan manfaat produk yang dihasilkan. Promosi jasa pendidikan dapat dilakukakan melalui pameran pendidikan, bazar pendidikan dan investasi, melakukan kontak langsung dengan siswa dan juga melakukan kegiatan hubungan dengan masyarakat.

People dalam konteks pendidikan adalah orang-orang yang terlibat dalam proses penyampaian jasa pendidikan, seperti Tata Usaha (TU), kepala sekolah, guru, dan karyawan (pendidik dan tenaga kependidikan). ${ }^{11}$ Sumber daya pendidik dan kependidikan ini sangat penting bahkan menjadi ujung tombak dalam proses pemberian layanan pendidikan kepada para siswa dalam lembaga madrasah.

Physical evidence adalah lingkungan fisik tempat jasa diciptakan dan langsung berinteraksi dengan konsumennya. ${ }^{12}$ Misalnya tata letak gedung, desain kelas, gedung perpustakaan, lapangan olahraga, raport, catatan siswa, dan blue print (cetak biru) sekolah seperti visi, misi, lingkungan belajar, rencana strategis sekolah, dokumen di tata usaha, dan lain sebagainya.

\footnotetext{
${ }^{8}$ Imam Machali dan Ara Hidayat, The Handbook of Education Management; Teori dan Praktik Pengelolaan Sekolah/Madrasah di Indonesia, (Jakarta: Kencana, 2016), 292.

'Imam Machali dan Ara Hidayat, The Handbook of Education Management; ..., 293.

${ }^{10} \mathrm{Imam}$ Machali dan Ara Hidayat, The Handbook of Education Management; ..., 293.

${ }^{11}$ Imam Machali dan Ara Hidayat, The Handbook of Education Management; ..., 293.

${ }^{12}$ Imam Machali dan Ara Hidayat, The Handbook of Education Management; ..., 293.
} 
Process adalah prosedur atau mekanisme dalam rangkaian aktivitas untuk menyampaikan jasa dari produsen ke konsumen. ${ }^{13}$ Dalam konteks jasa pendidikan proses adalah proses pendidikan yang mendukung terselanggaranya proses kegiatan belajar mengajar guna terbentuknya produk/lulusan yang diinginkan.

\section{Hasil dan Diskusi Penelitian}

1. Produk Jasa Pesantren

Pondok Pesantren Nurul Ulum Kabupaten Blitar menjadi salah satu lembaga pendidikan yang favorit dan menjadi pilihan bagi masyarakat Blitar dan sekitarnya, sekitar 25\% santri berasal dari luar Blitar. Bahkan menurut penjelasan dari Ustadz Ahmad Ulil Amin, Lc., M.S.I., Pondok Pesantren Nurul Ulum Kabupaten Blitar pernah menerima santri yang berasal dari luar negeri, seperti Malaysia dan Jepang.

Tabel 4.3 Latar Belakang Daerah Santri

\begin{tabular}{|c|l|c|c|}
\hline No. & \multicolumn{1}{|c|}{ Asal Daerah } & Jumlah & Persentase \\
\hline 1 & Blitar & 882 & $75,12 \%$ \\
\hline 2 & Tulungagung & 141 & $11,97 \%$ \\
\hline 3 & Kediri & 28 & $2,35 \%$ \\
\hline 4 & Malang & 47 & $4,00 \%$ \\
\hline 5 & Daerah Lain di Pulau Jawa & 55 & $4,69 \%$ \\
\hline 6 & Luar Jawa & 22 & $1,88 \%$ \\
\hline 7 & Luar Negeri & 0 & $0,00 \%$ \\
\hline
\end{tabular}

Sumber: Dokumentasi, Profil Pondok Pesantren Nurul Ulum Kabupaten Blitar

Dokumen pondok pesantren setidaknya mencantumkan tiga poin utama yang menyebutkan program-program unggulan Pondok Pesantren Nurul Ulum Kabupaten Blitar, yaitu penerapan sistem pesantren, penerapan pendidikan berbasis uswah, dan penggalakan gerakan "Pondokku Green and Clean". Tiga hal tersebut yang menjadi indikator utama dalam mengawal mutu dan kualitas pendidikan.

Program-program unggulan yang dimiliki Pondok pesantren Nurul Ulum Kabupaten Blitar telah terlaksana, walaupun masih perlu beberapa langkah perbaikan untuk hasil yang lebih maksimal. Keberhasilan program unggulan salah

\footnotetext{
${ }^{13}$ Imam Machali dan Ara Hidayat, The Handbook of Education Management; Teori dan Praktik Pengelolaan Sekolah/Madrasah di Indonesia, (Jakarta: Kencana, 2016), 294
} 


\section{Strategi Promosi Jasa Pendidikan di Pondok Pesantren Nurul Ulum \\ Kabupaten Blitar}

satunya juga terbukti dari capaian pondok pesantren Nurul Ulum kabupaten Blitar dalam mengawal dan mengantarkan MTs Ma'arif NU 2 Sutojayan dalam meraih akreditasi A dari Badan Akreditasi Nasional Sekolah/Madrasah (BAN S/M).

Pondok pesantren Nurul Ulum kabupaten Blitar dalam merealisasikan program unggulan juga terbukti berhasil dalam mendorong para santri untuk meraih berbagai macam prestasi dan kejuaraan. Setiap tahun sejak awal berdirinya, pondok pesantren Nurul Ulum kabupaten Blitar selalu meraih prestasi dan kejuaraan, baik dalam bidang seni, olahraga, keagamaan, olimpiade, pramuka, dan lain sebagainya.

2. Biaya Pendidikan Pesantren

Selama ini, Pondok Pesantren Nurul Ulum Kabupaten Blitar hanya mengandalkan syahriah sebagai sumber keuangan utama pesantren. Selain syahriah, yang juga ikut menopang pembiayaan pesantren adalah dana BOS (Biaya Operasional Sekolah). Selain itu, sumber pembiayaan juga diperoleh dari beberapa usaha dibawah unit KOPPONTREN NURUL ULUM (Koperasi Pondok Pesantren Nurul Ulum) dan sumbangan yang tidak mengikat.

Pembiayaan pendidikan di Pondok Pesantren Nurul Ulum Kabupaten Blitar dilaksanakan dengan prinsip transparansi, akuntabilitas, efektivitas, dan efisiensi. Pesantren dalam manajemen keuangannya selalu terbuka, penggunaan uang dapat dipertanggungjawabkan, pengelolaan uang dilakukan dengan sebaik mungkin, serta penerapan perbandingan yang terbaik antara masukan dan keluaran atau antara daya dan hasil.

Pondok Pesantren Nurul Ulum Kabupaten Blitar sebagai lembaga pendidikan nonprofil menjadikan kebutuhan pengeluaran sebagai dasar penentuan besaran biaya pendidikan. Pesantren tidak memiliki RAB (Rancangan Anggaran Biaya) pertahun. RAB sangat penting keberadaannya, apalagi dalam mengelola sebuah lembaga yang besar, rincian pembiayaan dan hal lain yang terkait keuangan harus mendapatkan perhatian yang lebih.

Setiap akhir tahun atau atau menjelang tahun ajaran baru, Pondok Pesantren Nurul Ulum Kabupaten Blitar melaksanakan evaluasi tahunan. Evaluasi akhir tahun tersebut berlangsung mulai pagi hingga sore hari, atau menyesuaikan dengan tuntasnya pembahasan. Sayangnya evaluasi tentang keuangan tersebut kurang 
efektif dilakukan, karena hanya membahas tentang keuangan pondok pesantren dalam tahun ajaran sebelumnya, tanpa membuat RAB atau perencanaan keuangan selanjutnya.

\section{Lokasi Pesantren}

Pondok Pesantren Nurul Ulum Kabupaten Blitar terletak di Lingkungan Dadapan, Kelurahan Kedungbunder, Kecamatan Sutojayan, Kabupaten Blitar, Provinsi Jawa Timur. Kabupaten Blitar merupakan salah satu daerah yang terletak di Pulau Jawa bagian timur dan berada di pesisir Samudra Hindia. Secara administratif, Kabupaten Blitar termasuk dalam Provinsi Jawa Timur dan berada di Barat Daya Surabaya (Ibu kota Provinsi Jawa Timur).

Gambar 4.6 Peta Kabupaten Blitar

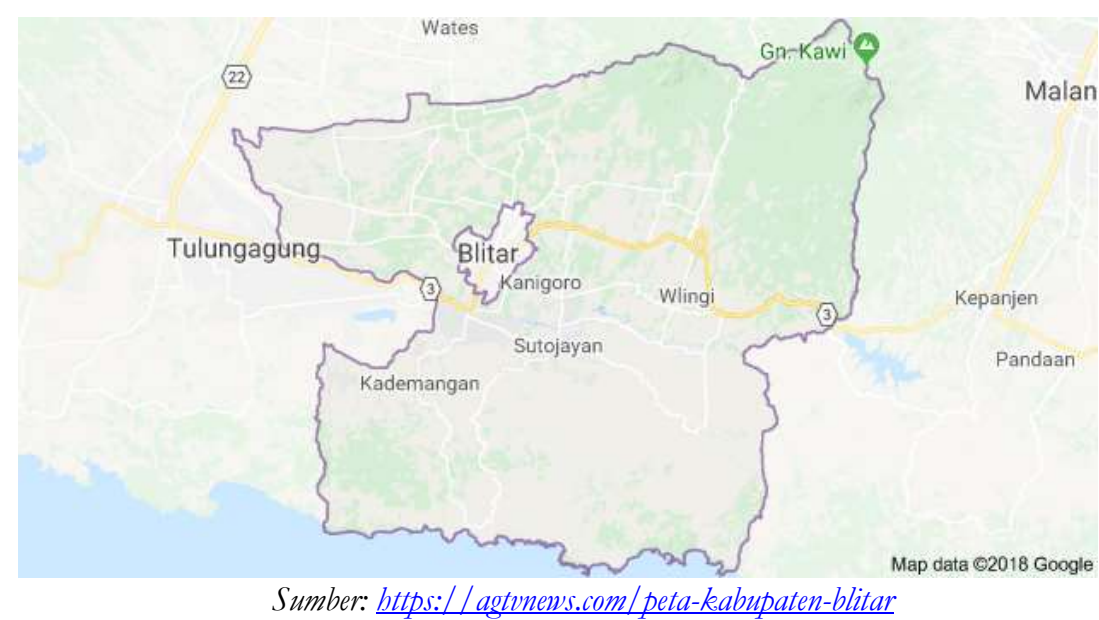

Sejak berdirinya, Pondok Pesantren Nurul Ulum Kabupaten Blitar terletak di lokasi yang cukup strategis. Gedung pesantren terletak di jalan raya yang ramai dan dekat dengan beberapa tempat penting. Di sebelah timur, berjarak $1 \mathrm{~km}$ terdapat Kota Lodoyo yang terkenal dengan Gong Kyai Pradah dan Pasar Besar Kota Lodoyo. Di sebelah barat, berdekatan dengan SMAN 1 Sutojayan dan area hutan lindung, sebagaimana di sebelah utara juga terdapat kawasan hutan jati.

Secara umum, Pondok Pesantren Nurul Ulum Kabupaten Blitar terbagi kedalam dua bagian, yaitu asrama putra dan asrama putri. Asrama putra berada di bagian utara pondok, sedangkan asrama putri berada di bagian timur pondok. Sehingga walaupun berada dalam satu daerah, interaksi antara santri putra dan santri putri sangat dibatasi. 


\section{Strategi Promosi Jasa Pendidikan di Pondok Pesantren Nurul Ulum}

Kabupaten Blitar

Pondok Pesantren Nurul Ulum Kabupaten Blitar terletak di Kabupaten Blitar berada pada ketinggian 167 mdpl dan termasuk dataran rendah. Kabupaten Blitar terletak antara $111^{\circ} 40^{1}-112^{\circ} 10^{1}$ Bujur Timur dan $7^{\circ} 58^{1}-8^{\circ} 9^{1} 51^{11}$ Lintang Selatan. Iklim Kabupaten Blitar termasuk tipe C.3 dimana rata-rata curah hujan tahunan 1.478,8 mm dengan suhu antara 18-30 Celcius. Pondok Pesantren Nurul Ulum Kabupaten Blitar berlokasi di daerah yang padat penduduk. Budaya masyarakat desa sangat terasa karena setiap pelaksanaan Sholat Jumat maupun agenda lain yang melibatkan masyarakat.

4. Kegiatan Promosi Pesantren

Pondok Pesantren Nurul Ulum Kabupaten Blitar melaksanakan kegiatan promosi dengan spontan dan kondisional. Promosi biasanya dilakukan hanya pada saat menjelang penerimaan santri baru (PSB). Dalam agenda evaluasi tahunan yang dilakukan, pesantren juga membahas tentang penyiapan PSB. Namun hanya secara umum dan tidak spesifik pada agenda promosi.Selain tanpa perencanaan, promosi Pondok Pesantren Nurul Ulum Kabupaten Blitar juga memiliki beberapa hambatan teknis yang cukup serius, salah satunya adalah terkait alokasi anggaran. Biasanya panitia hanya menyediakan beberapa lembar brosur pesantren di pos satpam dan beberapa banner dalam jumlah yang terbatas.

Gambar 4.10 Brosur Pondok Pesantren

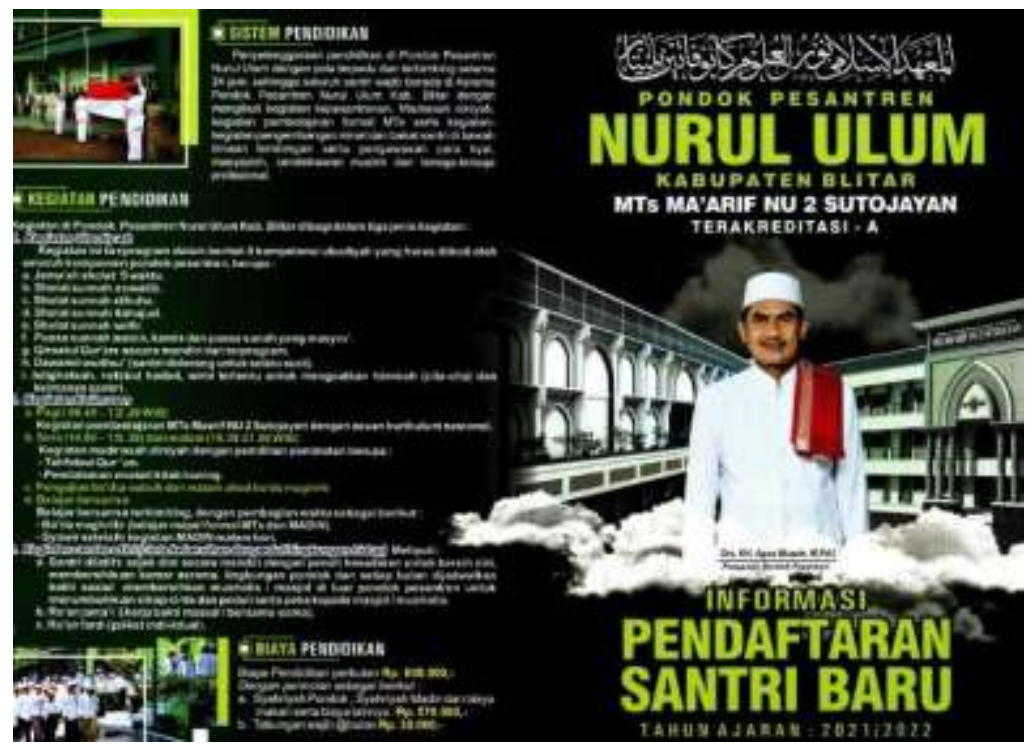




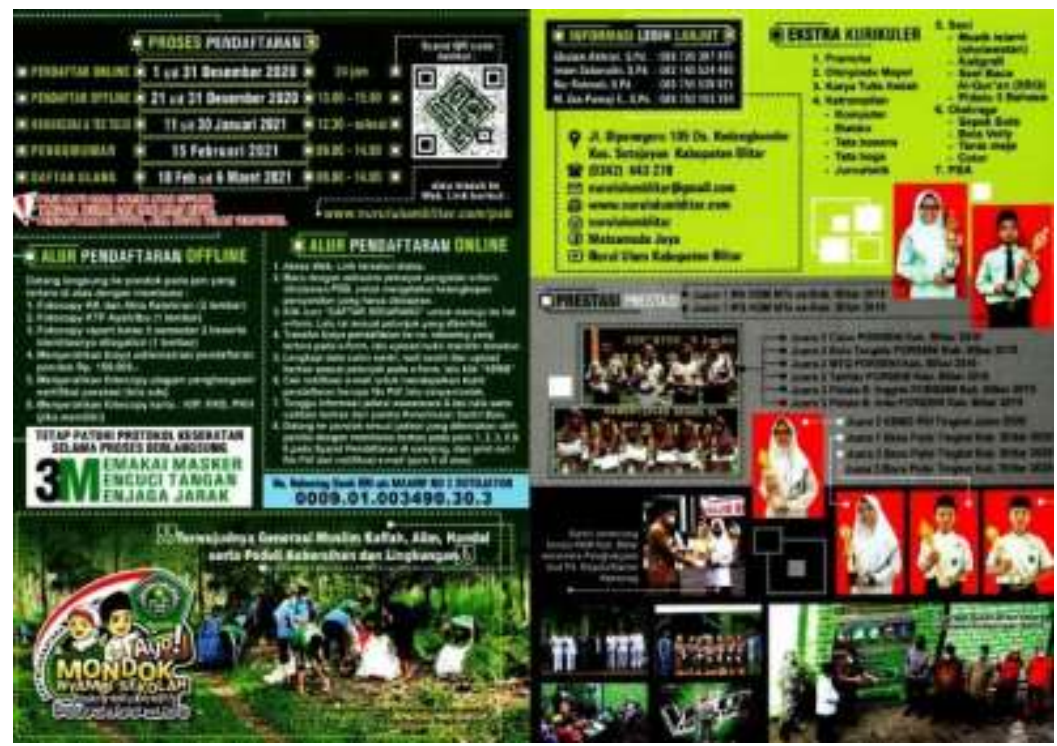

Sumber: Dokumentasi, Dokumen Tata Usaba

PSB (Penerimaan Santri Baru) yang bisa menjadi salah satu bagian kecil dari proses promosi juga tidak mendapatkan alokasi anggaran khusus yang ditetapkan setiap awal tahun. Pengajuan dana PSB juga hanya biasa saja sebagaimana kegiatan lain, anggaran PSB bisa diajukan 1-2 bulan sebelum pelaksanaan.

Setiap akhir tahun, Pondok Pesantren Nurul Ulum Kabupaten Blitar melakukan evaluasi dengan melibatkan seluruh pendidik dan tenaga kependidikan. Selain evaluasi akhir tahun, pondok pesantren juga pernah melaksanakan evaluasievaluasi lain apabila diperlukan. Namun memang tidak secara khusus mengevaluasi kegiatan promosi.

5. Sumber Daya Manusia Pesantren

Pondok Pesantren Nurul Ulum Kabupaten Blitar memiliki 183 orang yang terdiri dari pendidik dan tenaga kependidikan. Mereka diterima setelah melalui tahap rekrutmen terbuka. Pondok menetapkan beberapa kualifikasi umum yang harus dipenuhi diantaranya adalah sebagai berikut; (1) Muslim/ah, (2) Ahlussunnah wal Jamaah an-Nahdliyah, (3) Berakhlakul mulia, (4) Berpenampilan islami, (5) Sehat jasmani dan rohani, (6) Disiplin dan taat kebijakan pesantren, dan (7) Mampu bekerja dalam tim. Selain kualifikasi tersebut, ada beberapa kualifikasi khusus yang harus dipenuhi.

Selama ini proses seleksi rekruitmen Sumber Daya Manusia (SDM) Pondok Pesantren Nurul Ulum Kabupaten Blitar dilakukan berdasarkan kebutuhan. Pesantren tidak pernah menentukan waktu khusus untuk pembukaan atau penerimaan pendidik dan tenaga kependidikan. Apabila ada kekosongan peran 


\section{Strategi Promosi Jasa Pendidikan di Pondok Pesantren Nurul Ulum \\ Kabupaten Blitar}

atau jabatan, setelah melalui proses analisis yang dilaksanakan oleh pimpinan pondok, seleksi dapat dimulai.

Guru dan Tenaga Kependidikan Pondok Pesantren Nurul Ulum Kabupaten Blitar ditempatkan dalam unit tertentu berdasarkan pilihan ketika proses seleksi (pendaftaran). Namun apabila ada potensi lebih yang dimiliki dan berdasarkan persetujuan kiai, yang bersangkutan dapat ditambah tugas dalam unit yang lain. Rudi Asrori, S.Pd. misalnya, salah seorang guru di Madrasah Tsanawiyah yang mendapat tugas tambahan sebagai pendamping asrama putra.

Selain penambahan tugas dalam unit lain, Pondok Pesantren Nurul Ulum Kabupaten Blitar juga melakukan pemberdayaan sumber daya manusia dengan memberikan tambahan tugas dalam jabatan struktural. Misalnya seorang guru yang juga menjabat sebagai kepala madrasah, atau seorang pendamping asrama yang juga menjabat sebagai koordinator asrama, dan lain sebagainya. M. Zen Pamuji Eko, S.Pd., salah seorang guru yang juga menjadi Wakil Kepala Madrasah Tsanawiyah Bidang Kesiswaan.

Pondok Pesantren Nurul Ulum Kabupaten Blitar selalu berusaha meningkatkan kompetensi dan ketrampilan guru dan tenaga kependidikan. Setiap tahun, minimal sekali, Pondok Pesantren Nurul Ulum Kabupaten Blitar mengadakan program upgrading yang diikuti oleh seluruh SDM. Selain itu, program pelatihan juga biasa diadakan oleh instansi lain, mulai dari lembaga swasta, organisasi, hingga kementerian.

Pondok Pesantren Nurul Ulum Kabupaten Blitar belum memiliki SOP (Standar Operasional Prosedur) dalam melakukan evaluasi kinerja guru dan tenaga kependidikan. Pondok pesantren melakukan evaluasi kinerja guru dan tenaga kependidikan tanpa jadwal dan tahap yang pasti. Biasanya evaluasi dilakukan secara spontan dan kondisional oleh kiai dan pimpinan unit masing-masing. Evaluasi ini menghasilkan beberapa poin saran perbaikan dan catatan bagi setiap guru dan tenaga kependidikan.

6. Bukti Fisik Pesantren

Pondok Pesantren Nurul Ulum Kabupaten Blitar memiliki standar tersendiri dalam pengelolaan sarana dan prasarana pendidikan. Selama ini, pondok juga belum pernah mengikuti sosialisasi ataupun mendapatkan informasi terkait 
standar sarana dan prasarana pesantren. Sehingga selama ini sarana dan prasarana dikelola sebaik mungkin sesuai dengan kebutuhan yang ada.

Sarana dan prasarana yang tersedia di Pondok Pesantren Nurul Ulum Kabupaten Blitar sangat beragam. Diantaranya ruang kelas, musala, perpusatakaan, ruang tata usaha, ruang guru, ruang kepala, ruang bimbingan konseling, ruang organisasi siswa, ruang kesehatan, asrama, kantin, dan dapur umum.

Bangunan gedung Pondok Pesantren Nurul Ulum Kabupaten Blitar sangat bersih dan rapi. Namun memang kondisinya belum sesuai dengan kebutuhan, bahkan ada beberapa gedung yang dalam kondisi rusak. Bangunan yang rusak tersebut karena memang belum pernah diperbaiki sejak awal pendirian. Perbaikan gedung biasanya dilakukan hanya dengan mengandalkan keuangan internal pesantren dan ditambah dengan pemasukan lain yang tidak menentu.

Gambar 4.12 Gedung Pondok Pesantren, Kamar Mandi dan Tempat Jemuran

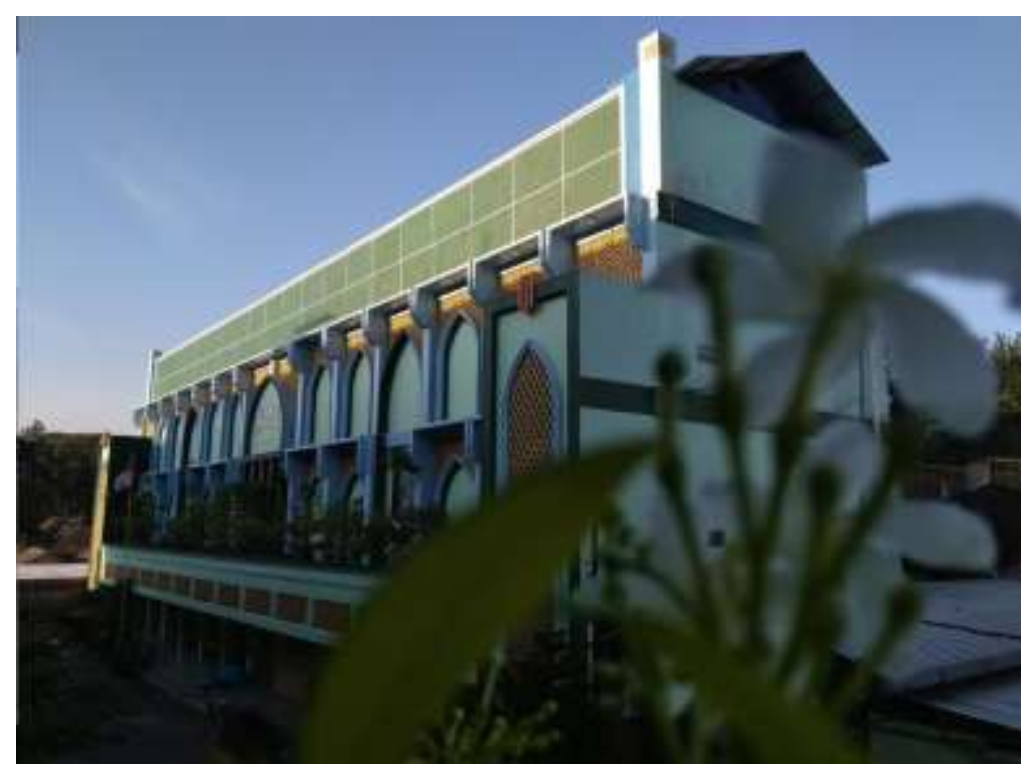




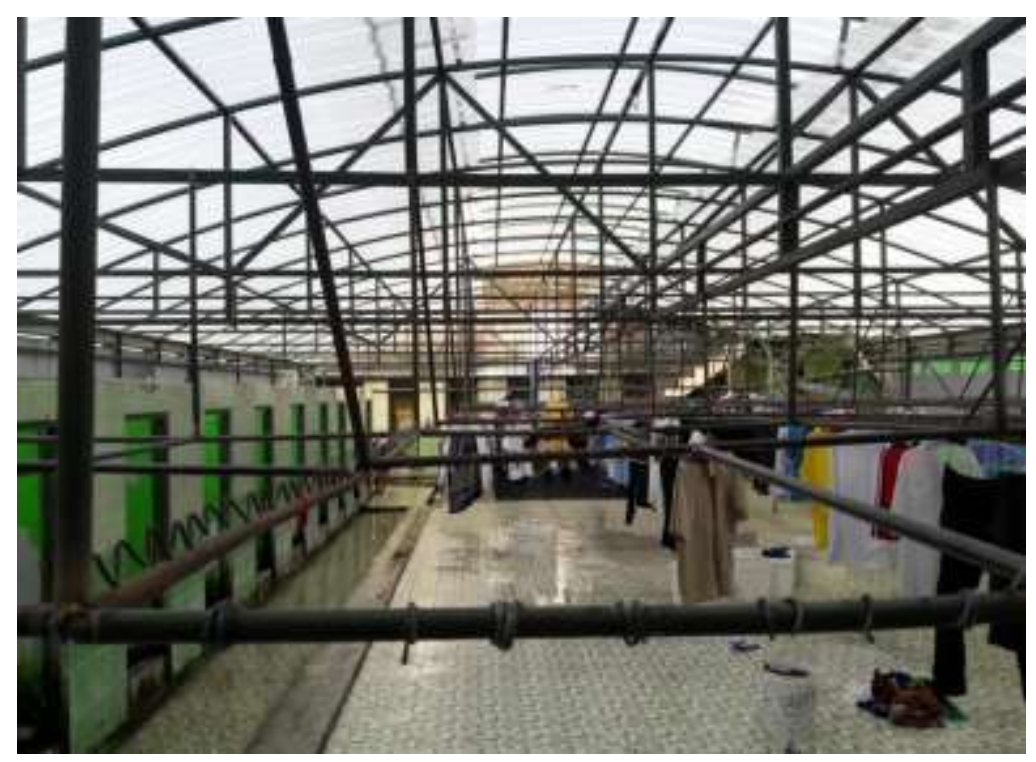

Sumber: Dokumentasi, Dokumen Tata Usaha

Pondok Pesantren Nurul Ulum Kabupaten Blitar telah memiliki blueprint dan master plan yang sangat menarik. Bahkan konsep dan rencana yang dimiliki dipersiapkan untuk 10 tahun mendatang. Menurutnya, blueprint dan master plan berisi rencana pembangunan dan pengembangan lokasi pondok pesantren.

Pengelolaan Arsip Pondok Pesantren Nurul Ulum Kabupaten Blitar cukup rapi walaupun belum maksimal. Masih ada beberapa catatan yang harus diperbaiki seperti kurangnya petugas (SDM), belum adanya sistem pengelolaan arsip yang baku, hingga belum tersedianya tempat penyimpanan yang akan digunakan. Kendati demikian, selama ini arsip dikelola oleh bagian tata usaha pesantren dengan berbagai kekurangan dan keterbatasan.

7. Proses Pendidikan Pesantren

Penyelenggaraan pendidikan di Pondok Pesantren Nurul Ulum Kabupaten Blitar menerapkan pola terpadu dan terbimbing selama 24 jam. Seluruh santri wajib berada di asrama dengan mengikuti seluruh kegiatan kurikuler kepesantrenan ala Ahlussunnah wal Jama'ah an-Nahdliyah yang meliputi; Madrasah Diniyah, pembelajaran formal Madrasah Tsanawiyah serta kegiatankegiatan pengembangan minat dan bakat santri di bawah binaan dan bimbingan serta pengawasan para kiai, masyayikh, cendikiawan muslim, dan tenaga profesional.

Pondok Pesantren Nurul Ulum Kabupaten Blitar menerapkan sistem pendidikan yang terintegrasi dengan Madrasah Tsanawiyah Maarif NU 2 Sutojayan 
dan Madrasah Diniyah Nurul Ulum Kabupaten Blitar. Santri yang tinggal di Pondok Pesantren Nurul Ulum Kabupaten Blitar, Santri Pondok Pesantren Nurul Ulum Kabupaten Blitar selain wajib mengikuti aktivitas kepesantrenan juga wajib mengikuti kegiatan madrasah tsanawiyah dan madrasah diniyah. Unit-unit ini saling mendukung dalam proses pendidikan dan memiliki peran dan porsinya masing-masing.

Tabel 4.7 Jadwal Kegiatan Santri

\begin{tabular}{|c|c|l|}
\hline No. & Waktu & \multicolumn{1}{|c|}{ Kegiatan } \\
\hline 1 & $\mathbf{0 3 . 3 0 - 0 4 . 3 0}$ & Sholat Lail, Persiapan Sholat Shubuh \\
\hline 2 & $04.30-05.00$ & Sholat Shubuh Berjama'ah \\
\hline 3 & $05.00-05.30$ & Pengajian Bakda Shubuh \\
\hline 4 & $05.30-06.30$ & Persiapan Sekolah dan Sholat Dhuha Berjama'ah \\
\hline 5 & $06.30-07.00$ & Berangkat ke Sekolah \\
\hline 6 & $07.00-12.40$ & KBM MTs \\
\hline 7 & $12.40-14.00$ & ISHOMA \\
\hline 8 & $14.00-15.40$ & KBM Madrasah Diniyah (Peminatan) \\
\hline 9 & $15.40-16.00$ & Sholat Asar Berjama'ah \\
\hline 10 & $16.00-16.30$ & Tadarus Al-Qur'an \\
\hline 11 & $16.30-17.30$ & Istirahat dan Persiapan Sholat Maghrib \\
\hline 12 & $17.30-18.00$ & Sholat Maghrib Berjama'ah \\
\hline 13 & $18.00-19.10$ & Belajar Bersama \\
\hline 14 & $19.10-19.30$ & Sholat 'Isya' Berjama'ah \\
\hline 15 & $19.30-21.20$ & KBM Madrasah Diniyah \\
\hline 16 & $21.20-03.00$ & Istirahat \\
\hline 17 & $03.00-03.30$ & Bangun dan Persiapan Sholat Malam \\
\hline
\end{tabular}

pendamping. Seorang pendamping bertugas untuk mendampingi 30-40 santri. Mereka bertugas di masing-masing asrama dengan dikomandoi oleh seorang coordinator pendamping asrama dan tetap berada di bawah pengawasan pengasuh pondok pesantren.

Berdasarkan visi, misi, tujuan, dan penyelenggaraan pendidikan sebagaimana dijelaskan sebelumnya, Pondok Pesantren Nurul Ulum Kabupaten Blitar menetapkan garansi kualitas minimal bagi santrinya sebagai berikut.

a. Bersikap dan berperilaku sopan (karakter santri)

b. Lulus dalam ujian akhir madrasah dan ujian nasional 


\section{Strategi Promosi Jasa Pendidikan di Pondok Pesantren Nurul Ulum \\ Kabupaten Blitar}

c. Mengkhatamkan Al-Qur'an dengan bacaan yang baik dan benar (tartil)

d. Mahir membaca Kitab Jurumiyyah (dengan tulisannya sendiri) dan hafal wazanwazan Amtsilatut Tasrifiyyah

e. Melaksanakan dan hafal aqidah serta ubudiyah An-Nahdliyah (wudhu, adzan, iqamah, shalat, qunut, wirid, dan tahlil)

f. Melaksanakan 9 (sembilan) ubudiyyah santri pondok

g. Memiliki minimal 2 (dua) kompetensi atau ketrampilan vokasional

h. Melaksanakan kegiatan peduli lingkungan hidup

\section{Kesimpulan}

Setelah melakukan penelitian melalui wawancara, analisa data yang tersedia, dan juga pengamatan secara langsung Pondok Pesantren Nurul Ulum Kabupaten Blitar belum memiliki rancangan dan strategi khusus dalam hal promosi. Namun tanpa disadari, secara tidak langsung pondok pesantren telah melaksanakan beberapa komponen dari bauran pemasaran yang ada. Adapun penerapan bauran pemasaran 7P di pondok pesantren sebagai berikut:

1. Promosi melalui penawaran produk jasa pesantren (product) telah berjalan meskipun belum ada program khusus yang disusun. Hal itu dapat dilihat dari reputasi pondok pesantren, program unggulan dan keberhasilannya, prestasi yang diraih, serta prospek lulusan pondok pesantren.

2. Promosi melalui penetapan biaya pendidikan pesantren (price) belum berjalan secara maksimal. Hal itu terbukti dari sumber pembiayaan pesantren yang masih minim dan pengelolaan biaya pendidikan yang terlaksana.

3. Promosi melalui pemilihan lokasi pesantren (place) telah berjalan, meskipun belum ada strategi khusus yang dilakukan. Hal tersebut dapat dilihat dari keadaan geografis, lokasi yang strategis, serta iklim dan budaya pondok pesantren.

4. Promosi melalui kegiatan promosi (promotion) pesantren tidak berjalan. Hal itu dikarenakan tidak adanya perencanaan kegiatan promosi, terbatasnya anggaran kegiatan promosi, serta tidak adanya evaluasi kegiatan promosi secara khusus dan mendalam.

5. Promosi melalui peningkatan kualitas sumber daya manusia (people) telah berjalan meskipun belum maksimal. Hal tersebut dapat dilihat dari proses rekruitmen, 
penempatan dan pemberdayaan, serta peningkatan kompetensi melalui berbagai macam pelatihan. Namun yang sangat disayangkan, pondok pesantren belum melakukan evaluasi kinerja sumber daya manusia sehingga kinerja belum dapat terukur dengan tepat.

6. Promosi melalui pemberian bukti fisik pesantren (physical evidence) telah berjalan, karena pondok pesantren telah memiliki gedung serta sarana dan prasarana yang memadai. Pondok pesantren juga sudah memiliki blueprint, hanya saja masih memerlukan proses penyempurnaan dan pengembangan. Selain itu, pondok pesantren juga sudah melakukan pengelolaan arsip.

7. Promosi melalui pelayanan proses pendidikan pesantren (process) telah berjalan. Pondok pesantren menyelenggarakan proses pendidikan dibawah bimbingan tenaga yang ahli dan terampil di bidangnya masing-masing. Kegiatan belajar mengajar serta kegiatan asrama berjalan dengan teratur dan rapi. Bahkan pondok pesantren juga memberikan garansi kualitas santri yang dijadikan sebagai batas minimal kualitas yang akan dicapai.

Berdasarkan pemaparan tersebut, dapat disimpulkan bahwa Pondok Pesantren Nurul Ulum Kabupaten Blitar belum maksimal dalam memanfaatkan bauran pemasaran dalam promosi jasa pendidikan. Pondok pesantren secara umum hanya berfokus pada bauran poduct, place, dan process dan masih sangat lemah pada bauran price dan promotion.

\section{Daftar Rujukan}

Charles W. Lamb, Joseph F. Hair, dan Carl McDaniel, Pemasaran. Jakarta: Salemba Empat, 2001

Kotler, Philip dan Amstrong, Gary. Dasar-Dasar Pemasaran. Jakarta: Intermedia, 1995.

Machali, Imam dan Hidayat, Ara. The Handbook of Education Management; Teori dan Praktik Pengelolaan Sekolah/Madrasah di Indonesia, Jakarta: Kencana, 2016.

Mawere, Dickens Ouma dan Simon, Kipkorir Sitienei Chris. "Technology and Performance Management: Strategies in Quality Service Delivery”. Global Journal of Management and Business Research, Volume XXI, Issue VI, 2021. 
Mudie, Peter dan Pirrie, Angela. Services Marketing Management. London: Routledge, 2011.

Noor, Zulki Zulkifli. Manajemen Pemasaran Stratejik dilengkapi dengan KasusKasus dalam Bidang Bisnis dan Sektor Publik Tahun 2016. Yogyakarta: Deepublish, 2020.

Sutisna, Oteng. Administrasi Pendidikan, Dasar Teoritis untuk Praktik Prefesional. Bandung, Aksara, 1985.

Zainal, Veithzal Rivai. Kamal, Haryadi dan Muhammad, Natsir. The Economics of Education; Mengelola Pendidikan secara Profesional untuk Meraih Mutu dengan Pendekatan Bisnis, Jakarta: Gramedia Pustaka Utama, 2014. 